\title{
MAJELIS TAKLIM ONLINE SEBAGAI WADAH PENDIDIKAN DAN PENGUATAN KARAKTER MAHASISWI POLITEKNIK ELEKTRONIKA NEGERI SURABAYA
}

\author{
Firdiyanti Al Ma'idha \\ Politeknik Elektronika Negeri Surabaya \\ Kampus ITS, Jl. Raya ITS, Keputih, Kec. Sukolilo, Kota Surabaya \\ Firdiyanti432@gmail.com \\ Elin Farichatul Jannah \\ Politeknik Elektronika Negeri Surabaya \\ Kampus ITS, Jl. Raya ITS, Keputih, Kec. Sukolilo, Kota Surabaya \\ elinfarichatu1254@gmail.com \\ Imamul Arifin \\ Politeknik Elektronika Negeri Surabaya \\ Kampus ITS, Jl. Raya ITS, Keputih, Kec. Sukolilo, Kota Surabaya \\ imamul@pens.ac.id
}

DOI: 10.46781/al-mutharahah.v18i1.232

\begin{abstract}
This research has the aim of describing the Taklim Online Council as a forum for education and character strengthening for students of the Surabaya State Electronics Polytechnic. Sources of information in this research are observations, informants (interviews), documentation, and literature studies. The author raises this theme because there are so many behavior changes, especially in students related to morals, and character. Even though students are a measure of the nation's future success. This research is based on theories from various experts and some take theories from internet sites. The results of the study show (1) the implementation of the Taklim Online Council as a forum for education and character strengthening for Surabaya State Electronics Polytechnic students, and (2) the role of the Online Taklim Council as a forum for education and character strengthening for the Surabaya State Electronics Polytechnic students. In this study, it can be seen that Majelis Taklim Online is a form of Character Building, namely as a solution in an effort to create and enforce one's morals and character, this is in accordance with the mission of the Prophet Muhammad SAW to strive for a good character.
\end{abstract}

Keywords: Majelis ta'lim; College student; Character.

\begin{abstract}
Abstrak
Penelitian atau riset ini memiliki tujuan yaitu mendeskripsikan tentang Majelis Taklim Online sebagai wadah pendidikan dan penguatan karakter bagi mahasiswi Politeknik Elektronika Negeri Surabaya. Sumber informasi pada riset ini adalah pengamatan, informan (wawancara), dokumentasi, dan studi literatur. Penulis mengangkat tema ini dikarenakan banyak sekali munculnya perubahan perilaku terutama pada mahasiswa terkait dengan akhlak, moral dan karakternya. Padahal mahasiswa merupakan tolak ukur keberhasilan bangsa di masa depan. Penelitian ini dilandasi oleh teori dari berbagai ahli dan beberapa mengambil teori dari situs internet. Hasil dari penelitian menunjukkan (1) pelaksanaan Majelis Taklim Online sebagai wadah pendidikan dan penguatan karakter mahasiswi Politeknik Elektronika Negeri Surabaya, dan (2) peran Majelis Taklim Online sebagai wadah pendidikan dan penguatan karakter mahasiswi Politeknik Elektronika Negeri Surabaya. Dalam penelitian ini dapat diketahui bahwa
\end{abstract}


Majelis Taklim Online merupakan salah satu bentuk Character Building yaitu sebagai solusi dalam upaya menciptakan dan menegakkan akhlak dan karakter seseorang, hal ini sesuai dengan misi Nabi Muhammad SAW adalah mengupayakan karakter yang baik (good character).

Kata kunci: Majelis ta'lim; Mahasiswa; Karakter.

\section{A. PENDAhULUAN}

Perkembangan dan kemajuan teknologi yang semakin tak terbatas dan tanpa batas tidak hanya berdampak pada perubahan tata kehidupan seperti pola hidup, akan tetapi juga memiliki dampak terhadap sikap dan perilaku mayarakat, terutama pada kalangan milenial tidak terkecuali mahasiswa. Hal ini dibuktikan dengan munculnya berbagai kasus pelanggaran yang sering terjadi seperti pelecehan seksual, penyalahgunaan narkoba (obat terlarang), hidup berfoya-foya, gaya hidup kebarat-baratan (westernisasi) dan munculnya gerombolan atau klub-klub yang meresahkan masyarakat dan lingkungan sekitar. Hal tersebut disebabkan rendahnya pendidikan dan penguatan agama terutama pada karakter yang tertanam pada diri masing-masing individu.

Dalam Islam, hal yang harus ada dan tidak dapat dipisahkan dalam diri manusia adalah agama dan karakter. Karena kualitas seseorang diukur berdasarkan akhlak dan karakternya. Hal tersebut sesuai dengan misi Nabi Muhammad Rasulullah SAW bahwa ajaran agama Islam adalah untuk menyempurnakan akhlak manusia. Beliau bersabda: "Aku diutus untuk menyempurnakan akhlak manusia." (HR. Ahmad dan Baihaqi). Menurut hadist tersebut menunjukkan bahwa pada prinsipnya ajaran yang dibawa oleh Nabi Muhammad Rasulullah SAW adalah berintensi pada pembentukan akhlak yang mulia, atau yang biasa dikenal dengan akhlakul karimah. Islam menekankan bahwa akhlak merupakan aspek penting dalam syariat Islam, karena menentukan bagaiamana kualitas seseorang dalam berbuat atau bertingkah laku. Sehingga akhlak merupakan salah satu hal yang wajib dimiliki oleh setiap muslimin dan muslimat. ${ }^{12}$

Oleh karena itu sangat diperlukan pendidikan dan peguatan akhlak dan karakter khususnya bagi generasi penerus bangsa, termasuk mahasiswa di tengah maraknya globalisasi dan westernisasi yang semakin membudaya di Indonesia. Karena mahasiswa merupakan tolak ukur keberhasilan bangsa, negara, dan agama di masa mendatang sehingga diperlukan karakter yang kuat agar mampu menjadi generasi pemimpin dan pelurus dan tentunya sesuai dengan syariat agama Islam. Salah satu hal yang dapat dilakukan dalam menyelesaikan persoalan tersebut adalah dengan memberikan pendidikan dan pendidikan dan penguatan karakter. Pemberian pendidikan dan penguatan karakter tersebut dapat melalui bimbingan keagamaan dalam bentuk kajian keislaman atau biasa disebut dengan Majelis Taklim sebagai bentuk pendidikan dan penguatan karakter mahasiswa. Hal ini sesuai dengan firman Allah SWT dalam Al-Qur'an surat At-Taubah ayat 122 yang berbunyi:

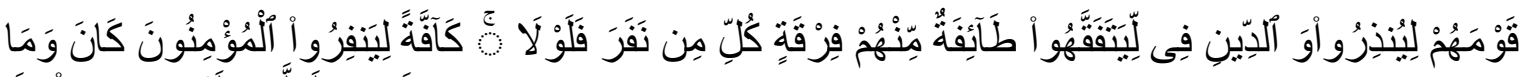

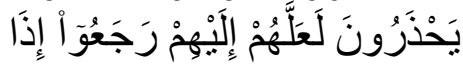

Artinya:

"Tidak sepatutnya bagi mukminin itu pergi semuanya (ke medan perang). Mengapa tidak pergi dari tiap-tiap golongan di antara mereka beberapa orang untuk memperdalam

${ }^{1}$ Yoke Suryadarma and Ahmad Hifdzil Haq, "Pendidikan Akhlak Menurut Imam Al-Ghazali," At-Ta'dib 10, no. 2 (2015): 362-81.

2 Suryadarma and Haq. 
pengetahuan mereka tentang agama dan untuk memberi peringatan kepada kaumnya apabila mereka telah kembali kepadanya, supaya mereka dapat menjaga dirinya."

Berdasarkan Ayat tersebut, disimpulkan pada Majelis Taklim akan diajarakan ilmuilmu syariat agama Islam yang tentunya memiliki keterkaitan pada pembentukan dan penguatan karakter. Disinilah Majelis Taklim berperan sebagai wadah dalam pendidikan dan penguatan karakter jamaahnya termasuk mahasiswa. Penelitian atau riset ini memiliki tujuan yaitu mendeskripsikan tentang Majelis Taklim Online sebagai wadah pendidikan dan penguatan karakter bagi mahasiswi Politeknik Elektronika Negeri Surabaya.

\section{B. METODE PENELITIAN}

Metode penelitian yang digunakan pada riset ini adalah jenis penelitian field research atau biasa dikenal dengan penelitian lapangan dengan menerapak metode kualitatif. Hasil dari penelitian ini yaitu data deskriptif yang didapatkan dari lapangan, tempat, atau wilayah penelitian. Penelitian ini merupakan suatu penelitian yang dilakukan secara sistematis dan analitis berdasarkan data yang ada di lapangan ${ }^{3}$. Selain itu, prosedur penelitian yang dihasilkan adalah berupa data deskriptif yang didapatkan dari kata-kata tertulis atau lisan dari orang-orang, dan kejadian atau perilaku yang diamati.

Penelitian ini dimaksudkan untuk medeskripsikan tentang pelaksanaan dan peran Majelis Taklim Online bagi mahasiswi Politeknik Elektronika Negeri Surabaya terkait pendidikan dan penguatan karakter. Data yang dikumpulkan dalam penelitian ini adalah menggunakan teknik observasi (pengamatan), wawancara, dokumentasi, dan juga studi literatur. Dalam hal ini studi literatur penting dilakukan karena data yang didapatkan bersifat akurat, dapat dipertanggungjawabkan, dan tentunya telah melalui penelitian yang teruji.

\section{PEMBAHASAN}

\section{Mahasiswa}

Menurut Santoso (2012), mereka yang sedang belajar dan menempuh pendidikan di perguruan tinggi baik akademi, institut, maupun universitas disebut sebagai mahasiswa. Akan tetapi makna dari mahasiswa itu sendiri tidak cukup demikian, melainkan makna yang luas. Mahasiswa merupakan kaum intelektual dan kaum cendekiawan yang menjadi generasi penerus bangsa dan diharapkan dapat bersaing serta mengharumkan nama bangsa. Adapun empat peranan mahasiswa adalah sebagai berikut:

\section{a. Agent of Change}

Mahasiswa merupakan fase terakhir seorang pelajar dalam menempuh pendidikan. Dengan memperoleh pendidikan yang tinggi diharapkan mahasiswa dapat menjadi agen perubahan bagi bangsa dan negara. Perubahan yang dimaksud adalah transformasi yang baik dan tentunya dapat memberikan hal yang positif terhadap perkembangan bangsa dan negara.

\section{b. Social Control}

Dengan pendidikan dan ilmu pengetahuan yang luas, mahasiswa harus mampu menjadikan diri mereka sebagai jembatan antara masyarakat dengan pemerintah agar dapat mengontrol kehidupan sosial masyarakat. Sehingga akan terciptanya kehidupan sosial yang teratur.

\section{c. Iron Stock}

Mahasiswa sebagai iron stock artinya memiliki peran sebagai aset berharga dan harapan bangsa di masa depan agar menjadi lebih baik. Sehingga diharapkan

${ }^{3}$ Dwi Rahmawati et al., "Process of Mathematical Representation Translation from Verbal into Graphic," International Electronic Journal of Mathematics Education 12, no. 4 (2017): 367-81. 
mahasiswa dapat menjadi sosok yang memiliki kapabilitas, kapasitas dan kualifikasi serta akhlak mulia agar dapat menggantikan generasi-generasi sebelumnya.

\section{d. Moral Force}

Sebagai mahasiswa harus memiliki tumpuan dasar dalam berperilaku seperti sikap, tingkah laku, perkataan, serta perbuatan yang baik. Sehingga nantinya dapat dijadikan sebagai kekuatan moral untuk negeri.

\section{Pendidikan dan Penguatan Karakter Mahasiswa}

Pendidikan karakter di perguruan tinggi dan universitas merupakan perpanjangan dari pendidikan karakter di sekolah. Oleh karena itu, di setiap perguruan tinggi harus memiliki perencanaan pembentukan karakter mahasiswa yang sesuai dengan visi, misi, dan karakteristik masing-masing perguruan tinggi. Sehingga, setiap perguruan tinggi dapat memiliki model pendidikan karakternya masing-masing. Pendidikan dan penguatan karakter harus dibentuk pada setiap universitas. Artinya ketika mahasiswa baru memasuki dunia perkuliahan, perguruan tinggi, program studi, dan organisasi perlu dikembangkan sepenuhnya sehingga dapat melatih para intelektual yang berkepribadian positif dan tentunya berprestasi seusai dengan tujuan pendidikan nasional.

Agus Wibowo meyakini bahwa fungsi pendidikan, pembentukan, dan penguatan karakter meliputi: (1) mengajar dan mengembangkan potensi peserta didik; (2) perubahan dan pembaruan; dan (3) sebagai penyaring. Agus Wibowo juga mengemukakan bahwa pendidikan dan penguatan karakter merupakan materi dasar utama pendidikan dasar, menengah, dan pendidikan tinggi (pelatihan kecakapan hidup). Idealnya adalah mengurangi proporsi pendidikan dan penguatan karakter di perguruan tinggi, karena dianggap asumsi tentang karakter siswa/mahasiswa sudah dibentuk pada pendidikan dasar. Namun pada faktanya sebagian besar kepribadian mahasiswa telah merosot, sehingga perlu bagi perguruan tinggi untuk mengadopsi strategi yang tepat dalam mengatasinya.

Adapun beberapa strategi yang dapat dilakukan dalam melaksanakan pendidikan dan penguatan karakter antara lain:

\section{a. Strategi moral knowing}

Strategi moral knowing adalah strategi untuk menanamkan pengetahuan yang baik kepada tiap individu berdasarkan prinsip-prinsip pendidikan dan penguatan karakter.

\section{b. Strategi moral modelling}

Strategi moral modelling adalah strategi dimana pendidik menjadi rujukan utama bagi peserta didik. Strategi ini menggunakan pendekatan karismatik, sehingga pemodelan moral dapat memberikan kontribusi yang besar bagi pendidikan, penguatan, dan pembentukan karakter. Oleh karena itu dibutuhkan teladan sebagai budi pekerti luhur dan sikap yang dimiliki hendaknya dapat ditiru dan ditransformasikam menjadi budi pekerti.

c. Strategi moral feeling and loving.

Untuk melahirkan moral, jiwa, kepribadian, dan karakter yang baik dapat juga menggunakan strategi moral feeling and loving. Strategi ini diwujudkan melalui memberikan kesan psikologis dan sikap positif. Dengan seseorang memiliki figure (panutan), pengetahuan, dan pemahaman mengenai sikap positif tersebut, maka akan muncul sikap positif pada diri individu. Oleh karena itu akan muncul rasa senang hati dari sikap tersebut dan kemudian akan mengikuti sehingga akan membentuk karakter yang posistif dengan sendirinya. 


\section{d. Strategi moral acting.}

Penerapan strategi ini adalah ketika seseorang memperoleh pengetahuan, menjadi panutan, dan dapat memahami pentingnya sikap positif, maka dengan sendirinya akan dengan senang hati mengikuti tindakan tersebut dan tentunya akan membentuk karakter yang baik.

e. Strategi tradisional (nasihat).

Strategi tradisional atau biasa juga disebut dengan strategi nasihat adalah strategi yang bertujuan untuk berkomunikasi secara langsung dengan seseorang tentang nilai-nilai baik dan buruk. Dengan strategi ini, pendidik memberikan arahan, informasi, dan bimbingan, serta mengajak peserta didik untuik mengarah kepada hal-hal kebaikan.

\section{f. Strategi punishment.}

Dengan adanya peraturan/ajaran maka akan terdapat hukuman/sanksi bagi pelanggarnya. Tujuan dari hukuman/sanksi adalah untuk benar-benar menekankan dan menegaskan aturan serta merupakan bagian dari penguatan karakter. Dengan menekankan dan menegaskan hal tersebut tentunya dapat menyadarkan pelanggarnya bahwa berada dalam kesalahan, sehingga mereka memiliki kesadaran untuk tidak mengulangi kesalahan tersebut dan memperbaiki diri.

\section{g. Strategi habituasi (pembiasaan)}

Strategi ini adalah strategi berbasis operasi yang sangat efektif dalam menanamkan nilai kebaikan terhadap peserta didik. Penerapan strategi secara perlahan dan terus dilatih/dibiasakan akan dapat menanamkan nilai-nilai kebaikan untuk diterapkan dalam kehidupan sehari-hari.

Dari tujuh strategi tersebut hendaknya dapat terus dilatih hingga konsep yang dibuat menjadi kebiasaan berpikir, kebiasaan batin, dan kebiasaan dalam bertingkah laku. Dengan menerapkan berbagai strategi tersebut, karakter yang mulia akan menjadi matang dalam jiwa manusia. Menurut Thimas Lickona, pemahaman tentang moralitas saja tidak cukup untuk menjadi manusia yang good character karena nilai moral harus dibarengi dengan kualitas moral yang baik pula. ${ }^{4}$

\section{Pendidikan Karakter dalam Perspektif Islam}

Dalam Islam, tujuan pendidikan dan penguatan karakter adalah menjadikan manusia memiliki kararakter yang mulia. Dalam hal ini yang menjadi acuan dasar adalah karakter Nabi Muhammad SAW, dan dasar pembentukan karakter tersebut adalah Al-Quran. Abdul Majid dan Dian Andayani mengutip jurnal internasional Moral Education yang menyatakan bahwa jurnal tersebut dielu-elukan sebagai hot topic yang meningkatkan relevansi pendidikan dan penguatan karakter. Pendidikan dan penguatan karakter ini memberikan makna nilai-nilai spiritual dan religius yang tidak dapat dipisakan dari budi pekerti luhur yang terdapat dalam diri manusia. ${ }^{5}$

Pendidikan dan penguatan karakter adalah langkah penting dan strategis untuk mengembalikan atau membangun kembali personalitas bangsa dan negara. Tidak ada disiplin ilmu yang terpisah-pisah dalam etika Islam. Bagi umat muslim, segala sesuatu yang dianggap halal dan haram dipahami sebagai keputusan Allah SWT. Selain itu, Islam memiliki tiga nilai dasar yang utama, diantaranya akhlak, adab, dan keteladanan.

Akhlak berhubungan dengan kewajiban umat muslim dalam menjalankan syariat dan ajaran agama Islam. Sedangkan adab mengacu pada hubungan yang

\footnotetext{
${ }^{4}$ Agus Wibowo, Managemen Pendidikan Karakter Di Sekolah (Yogyakarta: Pustaka Pelajar, 2013).

${ }^{5}$ Abdul Majid \& Dian Andayani, Pendidikan Agama Islam Berbasis Kompetensi Konsep Dan Implementasi Kurikulum 2004 (Bandung, 2004).
} 
berkaitan dengan tingkah laku. Dan keteladanan berhubungan dengan kualitas karakter umat Islam yang mengikuti Nabi Muhammad SAW.

\section{Majelis Ta'lim}

Kata "Majelis Taklim" berasal dari bahasa Arab yang terdiri dari dua suku kata, majelis (untuk tempat duduk) dan Taklim (untuk belajar). Dalam bahasa yang dimaksud Majelis Taklim adalah tempat untuk belajar. Secara terminologi, Majelis Taklim merupakan sebuah lembaga pendidikan informal dengan jumlah umat yang relatif banyak dari berbagai usia, membahas keagamaan, dan waktu yang fleksibel menyesuaikan kebutuhaan jamaahnya.

Helmawati mengatakan, Majelis Taklim merupakan wadah untuk bertukar pikiran, menjelaskan, dan memajukan ilmu dan keterampilan keagamaan serta keilmuan yang berulang-ulang sehingga dapat menjadi pencerah pada diri mutaalim sehingga ilmu yang diberikan menjadi bermanfaat. ${ }^{6}$

Melalui beberapa pemarapan diatas, disimpulkan bahwa Majelis Taklim merupakan tempat dimana ilmu agama Islam ditransfer dari Muallim ke Muataalim yang dilaksanakan secara rutin untuk memperluas ilmu agama, memperkuat keyakinan, dan mengedepankan akhlak yang luhur guna mewujudkan kebahagiaan dunia dan akhirat.

Abdul Jamil lebih jauh menyebut fungsi dan tujuan Majelis Taklim antara lain (1) Sebagai tempat belajar; (2) Sebagai lembaga pendidikan dan profesi; (3) Sebagai wadah aksi dan tempat berkreativitas; (4) Memiliki fokus pada positioning dan pengembangan; (5) Sebagai jaringan komunikasi dan wadah silaturrahmi untuk meningkatkan ukhuwah Islamiyah. ${ }^{7}$

Berdasarkan berbagai fungsi dan tujuan Majelis Taklim diatas, dapat diketahui bahwa Majelis Taklim merupakan badan atau tempat yang dapat memberikan pendidikan dan penguatan karakter bagi para jamaah. Seperti yang disebutkan sebelumnya, tujuan pemberian atau penyampaian ilmu pada Majelis Taklim terutama mencakup pengetahuan agama (aspek spiritual) dan pengetahuan umum, serta sebagian kecil melibatkan aspek keterampilan. Sehingga, Helmawati mengambil kesimpulan bahwa tujuan dibentuknya Majelis Taklim adalah untuk menjadikan manusia (jamaahnya) memiliki karakter keimanan yang kuat, berilmu, dan tentunya juga bertakwa.

\section{a. Karakter Beriman}

Majelis Taklim sebagai lembaga pendidikan agama secara informal dibentuk dengan mendidik dan mengajak masyarakat agar memiliki karakter yang beriman. Dengan ilmu agama yang didapatkan, para jamaah dapat menerapkan ilmu yang diajarkan agar menumbuhkan karakter beriman pada diri masing-masing individu. Dengan memiliki karakter beriman tersebut, tentunya dapat dipastikan bahwa mereka akan melakukan perbuatan yang diperintahkan oleh Allah SWT, dan menjauhi larangan-larangan-Nya, seperti kejahatan, membabi buta, pembunuhan, penggunaan alkohol, obat terlarang, narkoba, dan lain sebagainya.

b. Karakter Bertakwa

Dengan adanya penanaman ilmu yang diberikan pada Majelis Taklim, maka dapat memunculkan sikap taat kepada Allah dalam bentuk perintah dan larangan berdasarkan keimanan. Melaksanakan seluruh perintah dari Allah SWT dengan mengimani dan meyakini-Nya (rukun iman) serta meninggalkan hal-hal yang dilarang oleh-Nya. Helwamati berpendapat bahwa keimanan yang disertai dengan

\footnotetext{
${ }^{6}$ Helmawati, Pendidikan Nasional Dan Optimalisasi Majelis Ta'lim (Jakarta: Rineka Cipta, 2013).

7 T A Li, “M -Elis Ta'li” 111 (n.d.).
} 
amal sholeh berarti menunjukkan ketakwaan. Dari hal ini dapat diketahui bahwa Majelis Taklim dapat memunculkan karakter bertakwa pada para jamaahnya. Mengingat kondisi kehidupan kehidupan yang semakin rumit, ilmu dan pengetahuan agama yang diberikan oleh seorang muallim, dapat mendidik umat manusia senantiasa bertakwa kepada Allah SWT.

\section{c. Karakter Berilmu}

Orang-orang yang belajar di Majelis Taklim akan mendapatkan ilmu yang dibutuhkan, termasuk ilmu dunia dan juga ilmu akhirat. Seorang guru di Majelis Taklim dapat mendekatkan manusia kepada hal-hal baru yang belum pernah diketahui dan dipahami. Sehingga ilmu yang didapatkan dapat dijadikan petunjuk dari kegelapan menuju ke hal yang terang. Oleh karena itu, tidak dapat dipungikiri bahwa Majelis taklim hadir untuk mendorong dan membangun karakter berilmu pada umat manusia. ${ }^{8}$

\section{Pelaksanaan dan Peran Majelis Taklim Sebagai Wadah Pendidikan dan Penguatan Karakter Mahasiswa Politeknik Elektronika Negeri Surabaya}

Pedidikan dan penguatan karakter melalui kegiatan Majelis Taklim Online bagi mahasiswa Politeknik Elektronika Negeri Surabaya bertujuan untuk menekankan aspek spiritual dan material, dalam membentuk karakter islami bagi generasi penerus bangsa. Karena pada era digital ini banyak sekali kawula muda yang kehilangan moral, akhlak, dan budi pekerti dalam kehidupan kesehariannya. Melalui Majelis Taklim Online ini diharapkan para mahasiswi Politeknik Elektronika Negeri Surabaya dapat memiliki sikap dan perilaku sesuai dengan ajaran agama Islam berdasarkan Al-Qur'an.

Kegiatan Majelis Taklim Online ini diikuti oleh mahasiswi Politeknik Elektronika Negeri Surabaya khususnya program studi Teknik Komputer dan beberapa dari mahasiswi program studi lain. Kegiatan dilaksanakan melalui Zoom Conference sebanyak satu kali dalam satu pekan, yaitu pada hari Minggu sore dengan dibimbing oleh salah satu dosen Teknik Komputer, Ibu Reni Soelistijorini, B. Eng, MT. Kegiatan berupa pemberian materi dan kemudian dilanjutkan dengan tanya jawab. Materi yang diberikan sangat beragam, diantaranya adalah Aqidah, Syari'ah, dan Fiqih dengan berbagai judul seperti Keteladanan Nabi Muhammad SAW, Bagaiamana Cara Muslimah Berpakaian, Maulid nabi, Bukan cinta biasa, Darimana kita berasal, Menuntut ilmu, dan beberapa topik-topik lainnya.

Dalam keberlangsungan kegiatan Majelis Ta'lim, terdapat beberapa kendala yang sering di alami, diantaranya yaitu akses internet yang kurang memadai dan pemahaman materi yang kurang maksimal. Akses internet merupakan salah satu kendala yang cukup kerap dialami oleh para mahasiswa. Faktor utamanya yaitu adanya keterbatasan jaringan internet yang kurang stabil di daerah masing - masing mahasiswi. Sehingga dapat menghambat proses penerimaan materi yang telah disampaikan. Kemudian masalah berikutnya yaitu terkait dengan kuota, dimana apabila mahasiswi tidak menggunakan wifi dirumah maka harus mengeluarkan biaya untuk membeli kuota internet. Pembelian kuota internet ini juga dapat menjadi kendala apabila orang tua atau mahasiswa sedang kesulitan. Akibat dari akses internet yang kurang memadai, membuat proses Majelis Taklim Online menjadi terganggu, sehingga para mahasiswa yang mengikuti Majelis Taklim Online ini menjadi sulit untuk memahami materi yang diberikan.

Majelis taklim adalah kegiatan keagamaan yang didalamnya berisi pengarahan dan tuntunan terkait hal-hal keagaamaan (agama Islam). Majelis Taklim menjadi tempat, saluran, dan juga memfatwakan firman-firman Allah kepada para jamaah.

\footnotetext{
${ }^{8}$ Helmawati, Pendidikan Nasional Dan Optimalisasi Majelis Ta'lim.
} 
Majelis Taklim tidak hanya membahas hal-hal berhubungan dengan agama saja, melainkan juga sosial dan pendidikan. Di satu sisi, Majelis Taklim merupakan wadah pembinaan dan pengembangan kehidupan beragama, sehingga dapat membentuk pribadi yang berakhlakul karimah.

Melalui keberadaan Majelis Taklim Online, dapat dibuktikan dengan pengaruh yang dirasakan terhadap mahasiswi Politeknik Elektronika Negeri Surabaya. Majelis Taklim ini dampak pada spritual individu karena berkaitan dengan hubungan antara manusia dengan Allah SWT atau yang disebut dengan habluminallah. Mereka mengaku merasa dengan sang pencipta. Hal ini disebabkan oleh keikhlasan dan hati nurani saat mengikuti dan menerapkan ilmu didapatkan pada kegiatan Majelis taklim Online. Selain itu, dampak berikutnya adalah berhubungan dengan sosiologi seperti ketenangan, kenyamanan, dan ketentraman jiwa. Hal ini menunjukkan bahwa Majelis taklim Online telah memberikan pengaruh yang besar bagi Mahasiswi Politeknik Elektronika Negeri Surabaya.

Dalam hal ini, dapat diketahui bahwa Majelis Taklim Online merupakan salah satu bentuk Character building. Character building adalah jenis usaha yang dilakukan untuk membentuk karakter seseorang ke arah yang lebih baik. Dalam sejarah Islam, kurang lebih 1500 tahun yang lalu, Nabi Muhammad SAW juga mengaskan bahwa misinya adalah menjadikan umat manusia memiliki karakter yang baik (good character). Pelajaran pertama adalah nilai al-amien (kejujuran) dan bagaimana mengembangkan akhlak dan karakter yang baik. Oleh akrenia itu, diajarkan bahwa manuia harus senantiasa mampu untuk belajar (iqra), baik dari ayat-ayat tertulis maupun yang tidak tertulis (Q-Annes dan Hambali, 2008). ${ }^{9}$

Dalam pendidikan dan penguatan karakter, jumlah perilaku atau nilai yang dihasilkan memang penting, tetapi bukan yang terpenting. Yang terpenting adalah pembiasaan yang diterapkan dalam kehidupan sehari-hari. Kebiasaan ini akan membentuk kepribadian yang kuat pada kalangan mahasiswa. Selain itu, kebiasaan tersebut tentunya juga akan berpengaruh dan berguna ketika mereka tidak berada di kampus, melainkan di dunia kerja. Pendidikan dan penguatan karakter sangat penting bagi mahasiswa. Tanpa akhlak, moral, dan karakter yang kuat, kecerdasan dalam pendidikan dan ilmu dunia saja tidak cukup, melainkan dibutuhkan karakter yang positif serta memiliki rasa keimanan dan ketakwaan terhadap Allah SWT untuk mencipatkan generasi-generasi yang berkualitas. Oleh karena itu, Majelis Taklim online ini memiliki peranan yang sangat penting untuk mewujudkan hal tersebut. ${ }^{10}$

Dengan adanya Majelis Taklim Online sebagai wadah pendidikan dan penguatan karakter, dapat mendorong lahirnya mahasiswa berprestasi yang berkepribadian menarik, beretika, jujur, smart, peduli, dan kuat. Tumbuh dan berkembangnya karakter yang baik akan menginspirasi kemampuan dan tekad mahasiswa untuk bertumbuh, berbuat lebih baik, dan bermakna dalam hidup. Seseorang yang berkarakter dan ulet adalah orang yang berusaha melakukan yang terbaik untuk Allah SWT, untuk dirinya sendiri, orang lain, lingkungan, bangsa dan negara, bahkan dunia.

Pendidikan dan penguatan karakter pada Majelis Taklim online ini tidak hanya sebatas mentransfer ilmu pengetahuan saja, namun lebih dari itu, yakni bagaimana dapat mengubah atau membentuk karakter dan watak seseorang agar menjadi lebih baik, mempunyai skill yang mumpuni, lebih sopan dalam tataran etika dan estetika,

\footnotetext{
${ }^{9}$ Megawati, Pendidikan Karakter (Bandung: Pustaka Mizan, 2004).

${ }^{10}$ A. G. Agustian, Rahasia Sukses Membangun Kecerdasan Melalui Emotional Dan Spiritual Quotient (ESQ) (Jakarta: Arga, 2001).
} 
serta yang lebih penting adalah perilaku dalam kehidupan sehari-hari sesuai dengan syariat agama Islam. ${ }^{11}$

\section{SIMPULAN}

Dari penelitian yang telah dilakukan dapat diambil simpulan sebagai berikut:

1. Majelis Taklim bukan semata-mata berhubungan dengan aspek religius saja, tetapi terkait pula dengan aspek sosial, pendidikan dan politik. Kajian memiliki peran sebagai wadah untuk membina dan mengembangkan kehidupan beragama dalam rangka membentuk pribadi yang berakhlakul karimah seperti berkaitan dengan pendidikan dan penguatan karakter mahasiswi Politeknik Elektronika Negeri Surabaya.

2. Majelis Taklim merupakan salah satu bentuk Character building. Sebagai upaya untuk membangun dan membentuk akhlak dan budi pekerti seseorang menjadi baik sehingga memiliki peran penting dalam membentuk karakter seseorang sesuai dengan syariat agama Islam.

${ }^{11}$ K. D Dhiu and N Bate, "Pentingnya Pendidikan Karakter Di Perguruan Tinggi: Kajian Teoritis Praktis," Jurnal Ilmiah Pendidikan Citra Bakti 2017, no. November (2018): 172-76, ejournal.citrabakti.ac.id > jipcb > article > download. 


\section{DAFTAR PUSTAKA}

Agustian, A. G. Rahasia Sukses Membangun Kecerdasan Melalui Emotional Dan Spiritual Quotient (ESQ). Jakarta: Arga, 2001.

Andayani, Abdul Majid \& Dian. Pendidikan Agama Islam Berbasis Kompetensi Konsep Dan Implementasi Kurikulum 2004. Bandung, 2004.

Dhiu, K. D, and N Bate. "Pentingnya Pendidikan Karakter Di Perguruan Tinggi: Kajian Teoritis Praktis." Jurnal Ilmiah Pendidikan Citra Bakti 2017, no. November (2018): 172-76. ejournal.citrabakti.ac.id > jipcb > article > download.

Helmawati. Pendidikan Nasional Dan Optimalisasi Majelis Ta'lim. Jakarta: Rineka Cipta, 2013.

Li, T A. "M -Elis Ta'li" 111 (n.d.).

Megawati. Pendidikan Karakter. Bandung: Pustaka Mizan, 2004.

Rahmawati, Dwi, Purwanto, Subanji, Erry Hidayanto, and Rahmad Bustanul Anwar. "Process of Mathematical Representation Translation from Verbal into Graphic." International Electronic Journal of Mathematics Education 12, no. 4 (2017): 367-81.

Suryadarma, Yoke, and Ahmad Hifdzil Haq. "Pendidikan Akhlak Menurut Imam Al-Ghazali." At-Ta'dib 10, no. 2 (2015): 362-81.

Wibowo, Agus. Managemen Pendidikan Karakter Di Sekolah. Yogyakarta: Pustaka Pelajar, 2013.

\section{Internet}

Santoso, Budi. "Definisi, Peran Dan Fungsi Mahasiswa," 2012. http:/pamuncar.blogspot.com/2012/06/definisi-peran-danfungsi-mahasiswa.html.

\section{Wawancara}

Susfi Kusuma Wardani (Mahasiswa), wawancara oleh Firdiyanti Al Ma'idha, Politeknik Elektronika Negeri Surabaya. Tanggal 19 April 2021

Rena Kridianingrum (Mahasiswa), wawancara oleh Firdiyanti Al Ma'idha, Politeknik Elektronika Negeri Surabaya. Tanggal 19 April 2021 